\title{
Çocukluk Çağı Akciğer Hastalıklarında Sağlıklı Beslenmenin Önemi
}

\author{
The Importance of Healthy Nutrition in Childhood Lung Diseases
}

\author{
Nagehan EMIRALIOĞLU1', Dilek ASLAN²
}

${ }^{1}$ Hacettepe Üniversitesi Tıp Fakültesi, Çocuk Göğüs Hastalıkları Bilim Dalı, Ankara, Türkiye

${ }^{2}$ Hacettepe Üniversitesi Tıp Fakültesi, Halk Sağlı̆̆ı Anabilim Dalı, Ankara, Türkiye

\begin{abstract}
öz
Sağllklı beslenme akciğerlerin gelișiminde önemli bir role sahiptir. Birçok sistem üzerine olumsuz etkiye neden olan malnütrisyonun özellikle solunum sistemi gelişimi ve akciğer hastalıkları üzerindeki etkileri, ileri yașlarda solunum fonksiyonlarında kalıı bozulmaya yol açabilmektedir. Malnütrisyonun çocukluk çağında önlenmesi, erken tanınması ve gerekli müdahalelerde bulunulması morbidite ve mortaliteyi azaltmaya katkıda bulunacaktır. Bu derlemede; sağlıklı beslenmenin akciğer gelişimine etkisi, çocuklarda görülen malnütrisyonun akciğer hastalıklarının sıklı̆̆ına ve bu hastalıkların klinik gidişine etkilerinin tartışıması, çocukluk çağı akciğer hastalıklarında beslenme önerilerinin ve malnütrisyonu önlemeye yönelik çözüm önerilerinin incelenmesi, dünyada bu konuda alınan önlemlerin gözden geçirilmesi amaçlanmıştır. Bebeklik ve çocukluk dönemindeki malnütrisyonun akciğer sağliğı ve solunum fonksiyonlarına etkileri net bilinmemekle birlikte, yapılan çalıșmalar erken çocukluk dönemindeki malnütrisyonun solunum fonksiyonlarını olumsuz yönde etkilediğini göstermiştir. Malnütrisyon, hücresel immünite ve kazanımış immüniteye etkilerinin yanında akciğer gelișimine olan etkileri ile de solunum yolu enfeksiyonları sıkı̆̆ını ve riskini artırmaktadır. Bunların yanı sıra bu etkiler kronik akciğer hastalıkları gelişme riskini de artırmaktadır. Çocukluk çağında solunum yolu hastalıklarına bağlı ölümlerin büyük bölümü önlenebilir ölümlerdir. Ancak bu konuda etkili önlemlerin alınması ve uygun yaklaşımların yapılması önemlidir. Anne sütü alımının desteklenmesi, annenin gebelikte yeterli beslenmesi, mikrobesin ögelerinin alımının desteklenmesi, kronik solunum yolu hastalıklarında erken dönemde beslenme durumunun kontrol edilmesi ve önlemlerin alınması hastaların ileri yaştaki prognozunu olumlu etkileyecektir. Sonuç olarak; çocukların rutin izlemlerinde büyümenin, yeterli kilo alımı ve boy uzamasının olup olmadığının değerlendirilmesi önlenebilir sorunlarda erken müdahaleler açısından önemli bir yere sahiptir.
\end{abstract}

Anahtar Sözcükler: Çocukluk çağı akciğer hastalıkları, Malnütrisyon, Nutrisyon, Solunum fonksiyonları

\begin{abstract}
Nutrition has an important role in the development of the lungs. Malnutrition, which causes adverse effects on many systems, especially its effects on respiratory system development and lung diseases can lead to permanent impairment in respiratory functions in older ages. Prevention of malnutrition in childhood, early recognition and necessary interventions will contribute to reducing morbidity and mortality. In this review article, it is aimed to discuss the effects of nutrition on lung development, the effects of malnutrition on the frequency of lung diseases in children and the clinical course of these diseases, to evaluate nutritional suggestions and solutions to prevent malnutrition in childhood lung diseases, and to review the measures taken in this regard in the world. Although the effects of malnutrition in infancy and childhood on lung health and pulmonary functions are not known clearly, recent reports have shown that malnutrition in early childhood adversely affects the pulmonary functions. Besides, malnutrition has effects on both cellular and acquired immunity and on the frequency and risk of respiratory tract infections. Furthermore, all these influences increase the risk of developing chronic lung diseases. Majority of deaths due to respiratory diseases in childhood are preventable, however, it is important to take precautions and appropriate attitude in this regard. Supporting breastfeeding, adequate nutrition of the mother during pregnancy, supporting the intake of micronutrients, controlling the nutritional status in
\end{abstract}


the early period in chronic respiratory diseases and taking precautions will positively affect the prognosis of patients in older ages. In conclusion, evaluation of the growth, adequate weight gain and height in the routine follow-up of children have an important role in terms of early interventions in preventable conditions.

Key Words: Childhood lung diseases, Malnutrition, Nutrition, Pulmonary functions

\section{GiRiş:}

Sağlıklı beslenme akciğerlerin gelişiminde önemli bir role sahiptir. Malnütrisyonun, birçok sistem üzerine olumsuz etkisi bilinmekle birlikte özellikle solunum sistemi gelişimi ve akciğer hastalıkları üzerindeki etkileri, ileri yaşlarda solunum fonksiyonlarında kalıcı bozulmaya yol açabilmektedir (1).

Malnütrisyon, düşük ve orta gelirli ülkelerde yaşayan çocuklarda mortalitenin önemli nedeni olmaya devam etmektedir $(2,3)$. Bu durumun en önemli nedenlerinden biri malnütrisyonun enfeksiyonlara yatkınlık yapması ile birlikte, enfeksiyon hastalıklarının da malnütrisyona yol açmasıdır. Malnütrisyonun çocukluk çağında önlenmesi, erken tanınması ve gerekli müdahalelerde bulunulması morbidite ve mortaliteyi azaltmaya katkıda bulunacaktır (2-5).

Bu makalede; sağlıklı beslenmenin akciğer gelişimine etkisi, çocuklarda görülen malnütrisyonun akciğer hastalıklarının sıklığına ve bu hastalıkların klinik gidişine etkilerinin tartışııması, çocukluk çağı akciğer hastalıklarında beslenme önerilerinin ve malnütrisyonu önlemeye yönelik çözüm önerilerinin incelenmesi, dünyada bu konuda alınan önlemlerin gözden geçirilmesi amaçlanmıştır.

\section{Sağlıklı Beslenme ve Akciğer Gelişimine Etkisi}

Akciğerlerin gelişim süreci, biyokimyasal, mekanik ve anatomik farklı evrelerden oluşmakta olup postkonsepsiyonel 3. haftadan başlayarak tüm gebelik ve doğum sonrası dönemde de devam etmektedir ve bu gelişimin 22 yașına kadar sürdüğü bilinmektedir. Gebelik dönemi, doğum süreci ve doğumdan hemen sonra gelişen akciğer hasarı tüm yaşam boyunca akciğer sağlığı ve solunum fonksiyonlarını etkilemektedir. Bebeklik ve çocukluk dönemindeki malnütrisyonun ise akciğer sağlığı ve solunum fonksiyonlarına etkileri net bilinmemekle birlikte, bu dönemde yaşanan problemlerin de akciğer boyutlarını etkilediği gösterilmiştir $(1,6)$.

\section{- Fetal Dönemde Beslenme ve Akciğer Gelişimi}

Fetal yaşamda özellikle akciğerlerin sakkuler ve alveolar gelişim evrelerinde genetik ve epigenetik faktörler alveollerin gelişimini olumsuz etkilemektedir, intrauterin büyüme geriliğinin de iletici hava yollarının gelişimine olumsuz etkisi bilinmektedir (6). Bu konuda yapılan 5000 çocuğun incelendiği bir kohort çalışması intrauterin büyüme geriliğinin hava yolu direncini artırıp solunum fonksiyonlarını etkileyerek vizing ve astım gelişme riskine neden olduğunu göstermiştir (7). Düşük doğum ağırlığı ile doğan bireylerin erişkin yașta da maksimum solunum fonksiyonlarına ulaşamadıkları ve bu bebeklerde erişkin yașta kronik obstruktif akciğer hastalığı gelişme riskinin arttığı da bilinmektedir (8).

\section{- Postnatal Dönemde Beslenme ve Akciğer Gelişimi}

Doğumdan sonra hava yollarının boyutunda artış, alveollerin de hem sayısı hem de boyutlarında artış olmaktadır. Erken doğan bebeklerde, akciğer gelişiminde özellikle alveolar ve sakkuler evrede (Gebeliğin 24-40. haftası) beslenme önemli role sahiptir, bu nedenle de doğumdan sonra beslenme özellikle prematüre bebeklerde bu süreç postnatal dönemde de devam ettiğinden önemlidir. Bu bebeklerde yaşamın erken dönemde postnatal beslenmenin yeterli olmaması hiperoksinin alveoller üzerindeki olumsuz etkisini artırmaktadır; bu durumun da bronkopulmoner displazi patogenezinde etkili olacağı düşünülmektedir $(1,6)$.

Anne sütü ile beslenmenin ilk iki yașta viral enfeksiyonların neden olduğu vizinge karşı koruyucu olduğu bilinmektedir (9). Bu etkinin anne sütünün bağışıklık sistemini güçlendirici etkisine bağlı çocukluk çağı viral enfeksiyonlarının sıklığını azaltmasıyla ilişkili olduğu düşünülmektedir. Bu konuda yapılmış bir sistematik derlemede; özellikle 4 ayın üzerinde anne sütü ile beslenen bebeklerin formula besin alan bebeklerle karşılaştırıldığında solunum fonksiyonlarının daha iyi olduğu görülmüştür (10). Bu bilgiler anne sütünün akciğer maturasyonunda görevli TGF beta gibi sitokinler ve büyüme faktörlerini aktive ederek akciğerlerin gelişimini olumlu etkilediğini ve ileri yaştaki solunum fonksiyonlarını olumlu etkileyeceğini düşündürmektedir (6).

\section{- Bebeklik ve Çocukluk Döneminde Beslenme ve Akciğer Gelişimi}

Bebeklik ve çocukluk döneminde beslenmenin akciğer gelişimine etkileri ile ilgili yeterli sayıda çalışma bulunmamaktadır. Alveoler gelişimin iki yaşına kadar devam ettiği bilindiğinden bebeklerdeki malnütrisyonun daha geç çocukluk dönemindeki malnütrisyonla karşılaştırıldığında akciğer sağlığını ve akciğer gelişimini olumsuz yönde etkilediği tahmin edilmektedir. Bu konudaki kohort çalışmaları da bu görüşü desteklemektedir. Özellikle erken çocukluk dönemindeki malnütrisyonun solunum fonksiyonlarını olumsuz yönde etkilediği gösterilmiştir $(6,11)$.

\section{Malnütrisyonun Tanımı ve Çocuklarda Malnütrisyonun Etkileri}

Dünya Sağlığı Örgütü (DSÖ) malnütrisyonu; kişinin enerji ve / veya besin alımındaki eksiklikler, aşırılıklar veya dengesizlikler olarak ifade eder. Buna göre malnütrisyon üç alt başlığa ayrilabilir (12):

a. Yetersiz beslenme: Zayıflık (boya göre düşük ağırlık), bodurluk (yaşa göre düşük boy) ve düşük kiloluluk (yaşa göre düşük ağırlık).

b. Mikro besinlerle (Vitamin, mineraller) ilgili yetersiz beslenme: Mikro besin eksikliklerini veya mikro besin fazlalığını içerir. 
c. Fazla kiloluluk: Obezite ve diyetle ilgili bulaşıcı olmayan hastalıklara bağı durumlar (kalp hastalığı, diyabet gibi).

Dünya Sağlığı Örgütü 2020 yllı verilerine göre 5 yaş altı çocuklarda 47 milyon çocukta zayıfllk, 144 milyon çocukta bodurluk ve 38.3 milyon çocukta fazla kiloluluk durumunun önemli bir sağılık problemi olduğu görülmektedir. Beş yaş altı çocuk ölümlerinin \%45'inin yetersiz beslenme ile ilişkili olduğu bildirilmiştir. Bu durum düşük ve orta gelirli ülkelerde önemli bir sağlık sorunu olmaktadır. Malnütrisyonun ekonomik, sosyal ve tıbbi etkileri dünyada da önemli bir problem olmaya devam etmektedir. Özellikle kadınlar, bebekler, çocuklar ve adolesanlar malnütrisyon açısından risk altındadırlar. Bu nedenle de özellikle konsepsiyon sonrası 1000 günü içeren yaşamın erken dönemlerinde beslenmenin düzenlenmesi ve gereken önlemlerin alınması uzun dönem etkileri nedeniyle önemlidir (12).

Yoksulluk, yetersiz beslenme ve buna bağlı riskleri artırmaktadır. Yoksul insanların malnütrisyondan etkilenme olasılı̆ı daha yüksektir. Ayrıca, yetersiz beslenme sağlik hizmetleri maliyetlerini artırmakta, üretkenliği düşürmekte ve ekonomik büyümeyi yavaşlatmaktadır, bu durum da yoksulluk ve hastalık döngüsünü devam ettirmektedir (12).

Yetersiz beslenen çocuklarda enfeksiyöz hastalık sıkliğının artmasına ek olarak, daha șiddetli hastalık riski mevcuttur ve bu durum enfeksiyon durumunda akut dönemde ve kronik süreçte mortalite ve morbiditenin önemli nedenidir (2).

Malnütrisyon, hücresel immünite ve kazanılmış immüniteye etkilerinin yanında akciğer gelişimine olan etkileri ile de solunum yolu enfeksiyonları sıklı̆ını ve riskini artırmakla birlikte kronik akciğer hastalıkları gelişme riskini de artırmaktadır. Şekil 1'de malnütrisyonun akciğer gelişimi ve akciğer hastalıkları üzerine etkileri özetlenmiștir (13).

\section{Akciğer Hastalıkları ve Malnütrisyon İlișkisi}

Solunum sistemi hastalıkları, mortalite ve morbiditenin önemli nedeni olan hastalıklardır. Bebekler ve çocukların akciğer hastalıklarına daha hassas olduğu; özellikle düşük ve orta gelirli ülkelerde akciğer enfeksiyonlarının önemli bir mortalite nedeni olduğu bilinmektedir (14). Beş yaş altı çocuk ölümlerine bakıldığında yllık 6.6 milyon çocuk ölümünün olduğu ve her yll 1.3 milyon çocuğun pnömoni nedeniyle kaybedildiği görülmektedir; pnömoniler bu ölümlerin önemli nedenini oluşturmaktadır (15). Buna ek olarak malnütrisyon veya HIV enfeksiyonu da çocuklarda ölüm sayısında artışın önemli nedenlerindendir. Malnütrisyon sadece pnömoni riskinde artış ile ilişkili değil, aynı zamanda hastalığın ciddi seyrinde ve buna bağlı ölümlerle de yakından ilişkilidir (14). Malawi'de yapılan ve 16475 çocukluk pnömoni olgusunun değerlendirildiği bir çalışmada ağır malnütrisyonun hipoksemi ile benzer şekilde mortalite riskini artırdığı gösterilmiştir (16). Kenya'da yapılan 4187 çocuğun alındığı başka bir çalışmada da hastanede yatırılan ağır pnömoni hastalarının \%25'inin malnütrisyonunun olduğu ve bu durumun pnömoni ağırlı̆ı ile birlikte hastanedeki mortaliteyi artırdığı gösterilmiştir (17).

Tüberküloz, HIV prevalansı ve malnütrisyon sıklğı fazla olan ülkelerde mortalite ve morbiditenin önemli nedenlerinden biridir. Çocuklarda mikrobiyolojik tanı koymadaki zorluklar nedeniyle çocukluk çağı tüberküloz yükünün doğru bir şekilde ölçülmesi zor olsa da, insidansı yüksek ülkelerde çocukların ülkenin toplam tüberküloz yükünün \%15 ila \%20'sini oluşturduğu tahmin edilmektedir (14). Malnütrisyonu olan çocuklarda artmış tüberküloz riskinin nedeni, malnütrisyonun sekonder immün yetmezliğe neden olarak konağın enfeksiyonlara yatkınlığını artırmasıdır. Malnütrisyon hücre içi enfeksiyonlara ve ölüme neden olan önemli bir risk faktörü olduğundan beslenme durumunun bozulması, latent enfeksiyonun reaktivasyonuna da neden olabilir. Tüberküloz tedavisi sırasında beslenme durumu iyi olan çocukların tedavi yanıtlarının daha iyi olduğu gösterilmiştir (18). Bazı düşük ve orta gelirli ülkelerde malnütrisyon ile akciğer hastallkları yükü arası ilişki Tablo I'de sunulmuştur (19-22). Bu çalışmalar da ağır malnütrisyonu olan çocuklarda pnömoni,

Tablo I: Düşük ve Orta Gelirli Ülkelerde Malnütrisyonu Olan Çocuklarda Akciğer Hastalıkları Yükü.

\begin{tabular}{|c|c|c|c|c|c|}
\hline Referans & YII & Ülke & Çalışma tipi & Çalışma grubu & Bulgular \\
\hline Munthali ve ark. ${ }^{(19)}$ & 2015 & Zambia & Gözlemsel & $\begin{array}{l}5 \text { yaș altı ağır } \\
\text { malnütrisyonu olan } 9450 \\
\text { çocuk }\end{array}$ & $\begin{array}{l}\text { En sık morbiditeler: \%25.3 pnömoni, } \\
\% 5.3 \text { septisemi, \%6.8 tüberküloz }\end{array}$ \\
\hline Agarwal ve ark. (20) & 2015 & Hindistan & Gözlemsel & 5 yaş altı 458 çocuk & $\begin{array}{l}\text { Malnütrisyon son üç aydaki akut } \\
\text { solunum yolu enfeksiyonu sıkıı̆ını } \\
\text { artırıyor (OR=1.58). }\end{array}$ \\
\hline Chisti ve ark. (21) & 2013 & $\begin{array}{l}\text { Güney } \\
\text { Afrika, } \\
\text { Etopya, } \\
\text { Gambia, } \\
\text { Tayland }\end{array}$ & $\begin{array}{l}\text { Gözlemsel } \\
\text { çalışmaların } \\
\text { derlemesi }\end{array}$ & $\begin{array}{l}5 \text { yaș altı ağır } \\
\text { malnütrisyonu olan } 747 \\
\text { çocuk }\end{array}$ & \%12 aktif tüberküloz \\
\hline Bhat ve ark. (22) & 2013 & Hindistan & Gözlemsel & $\begin{array}{l}\text { Akut alt solunum yolu } \\
\text { enfeksiyonu olan } 5 \text { yaş altı } \\
107 \text { çocuk }\end{array}$ & $\begin{array}{l}\text { Malnütrisyon, akut alt solunum yolu } \\
\text { enfeksiyonu gelişme riskini artıriyor } \\
\text { (OR=1.75 \%95 GA=1.84-3.67). }\end{array}$ \\
\hline
\end{tabular}




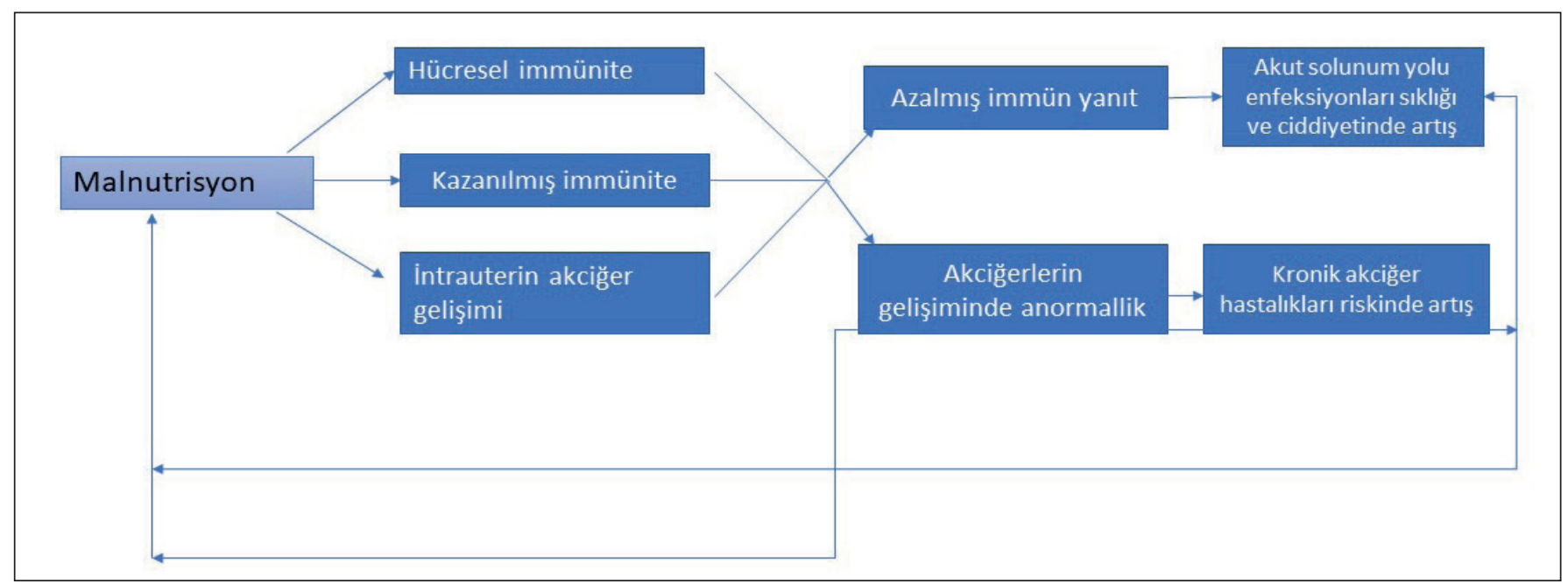

Şekil 1: Malnütrisyon, akciğer gelişimi ve akciğer hastalıkları ilişkisi.

tüberküloz riskini ve hastalığa bağlı artmıș mortalite oranını göstermektedir.

Son yıllarda çocukluk çağı obezitesinin prevalansında artışla birlikte, bu artışın akciğer sağlığına etkileri de önemli bir sorun haline gelmeye bașlamıştır (23). Uzun dönemli çalıșmalar, obezitenin çocukluk çağı astımı gelişme riskini artırdığını göstermiștir (24). Obezitenin solunum fonksiyonlarına olan etkisi bronş hiperreaktivitesi ve obezitenin etkisi ile gelişen sistemik inflamasyonla açıklanabilir (25). Obezitesi olan çocuklarda adipoz dokuda biriken makrofajların ürettiği inflamatuar sitokinler ve adipokinlerin etkisi ile akciğer ve immün sistem doğrudan etkilenmektedir, bu durum sistemik inflamasyon patogenezinde önemlidir. Diğer bir neden de özellikle karın ve göğüs kafesindeki yağ kitlesinde artış, akciğerlerin ve göğüs kafesinin genişlemesini engelleyen bir sorun olduğundan solunum fonksiyonlarında düşmeye yol açmaktadır (26).

Obezitenin astım ile nedensel ilişkisi konusunda farklı çalışmalar bulunmaktadır $(26,27)$. Erken okul çağı döneminde aşırı kilolu veya obezitesi olan çocuklarda ergenlik döneminde astım riskinin arttığı gösterilmiştir. Bu çocukların astıma bağlı solunum fonksiyonlarında düșme ile ilișkili olarak günlük fiziksel aktivitelerinin kısıtlanması da obeziteye neden olan önemli bir durumdur (28). 2016 ve 2020 yıllarında yayınlanan iki farklı sistematik derlemede obezitesi olan çocuklar ve ergenlerin akciğer volümleri ve kapasitesinde düșme olduğu bildirilmiștir $(26,27)$.

Çocukluk çağı obezitesinin neden olduğu durumlardan biri de obstruktif uyku apnesidir ve bu durumun farkındalığının az olması tanıda gecikmelere neden olmaktadır (23). Çocukluk çağı obezitesinin obstruktif uyku apnesi gelişiminde bağımsız bir risk faktörü olduğu gösterilmiştir (29). Astımla benzer şekilde bu çocuklarda da görülen azalmış egzersiz kapasitesi obezitenin artışına neden olmaktadır $(24,29)$.

\section{- Mikrobesinler ve Akciğer Hastalıkları ile İlişkisi}

Mikrobesinler, akciğerlerin doğumdan önce gelişiminde önemli bir rol oynar ve akciğer gelișiminin kritik așamalarındaki eksiklikleri, erken doğan bebeklerde solunum morbiditesi ve sonraki yaşamda vizing insidansının artışı üzerinde etkiye sahip olabilir (30). Mikrobesinlerle ilișkili malnütrisyon enfeksiyonlara yatkınlığı ve ağır hastalık geçirme riskini artırmakta; iyileşmeyi geciktirmektedir. Annedeki eksiklikler, bebeklerde olumsuz etkilere neden olmaktadır. Vitamin A, C, D, çinko, demir ve folik asit önemli mikrobesinler olup çocuklarda enfeksiyon hastalıklarının önlenmesinde ve tedavisinde kullanılan önemli mikro besinlerdir (2). Vitamin A, akciğer gelişiminde rol oynamaktadır ve enfeksiyonlara karşı immünolojik yanıtta etkilidir; eksikliği çocuklarda mortalite ve morbidite ile ilişkili bulunmuștur. Vitamin D'nin de immunomodulatuar etkileri ile enfeksiyonlara karşı koruyucu olduğu düşünülmektedir. Yine yeterli C vitamini ve çinko alımının immünolojik fonksiyonları artırarak pnömoni gibi enfeksiyonlara bağı morbiditeyi azalttığı gösterilmiştir $(2,6)$.

\section{4. Çocukluk Çağı Akciğer Hastalıklarında Sağlıklı Beslenmeye Yönelik Öneriler}

Çocukluk çağında solunum yolu hastalıklarına bağlı ölümlerin büyük bölümü önlenebilir ölümlerdir. Ancak bu konuda etkili önlemlerin alınması ve uygun yaklașımların yapılması önemlidir. Bu önlemlere uyulmasıyla pnömoniye bağlı ölümlerin \%65'inin 2025 yllına kadar önlenebileceği düșünülmektedir. Bu durumun da sağlık hizmetlerine ulaşımın artırıması, beslenmenin iyileștirilmesi, anne sütü alımının desteklenmesi, yaşam koşullarının düzeltilmesi, ev içi ve ev dışı hava kirleticilerinin azaltılması ile mümkün olacağı düşünülmektedir (12).

\section{- Çocuklarda Akut Solunum Yolu Hastalıklarında Beslenme Önerileri}

\section{a. Anne sütü ile beslenme:}

Anne sütü ile beslenme, düşük ve orta gelirli ülkelerdeki çocuklarda enfeksiyon sıklığını azaltmakta ve yaşam süresini uzatmaktadır. Bu kadar güçlü kanıtlara rağmen dünyada her beș çocuktan sadece ikisi ilk altı ayda anne sütü almaktadır. Anne sütünün yetersiz alımına bağı gelișen akciğer enfeksiyonlarını 
azaltmak için, anne sütünü desteklemeye yönelik eğitimlerin verilmesi önemlidir (2). Filipinler'de yapılan bir çalışma, anne sütü ile beslenme eğitim programı sonrası 2-7 ay arası bebeklerin kontrollere göre daha sağlıklı olduklarını göstermiştir (31). Anne sütünün buna ek olarak aşıya karşı gelişen antikor yanıtını artırdığına dair de kanıtlar bulunmaktadır (2).

\section{b. Annenin gebelikte yeterli beslenmesi:}

Annenin gebelikte yeterli beslenememesi yenidoğanın büyüme ve gelişimi üzerinde olumsuz etkilere yol açabilir (2). Bu nedenle de gebeliği süresince annenin beslenmesi desteklenmeli ve mikrobesin eksiklikleri önlenmelidir. Bangladeş'te yapılan randomize kontrollü bir çalışmada annenin gebelikte çinko alımının bebeğin büyümesini etkilediği ve enfeksiyon hastalıklarına bağlı morbiditeyi azalttığı gösterilmiştir (32).

\section{c. Mikrobesin ögelerinin desteklenmesi:}

Vitamin A desteğinin, solunum sistemi enfeksiyonlarına etkisini araştıran farklı çalışmalar bulunmaktadır. Dünya Sağlık Örgütü'nün vitamin A ve pnömoni çalışma grubu, gelişmekte olan ülkelerde vitamin A desteğinin pnömoni insidansını $(R R=0.95 \% 95$ Güven Aralığı=0.89-1.01) etkilemediğini göstermiştir. Vitamin A desteği 6 ay-5 yaş arası çocuklarda kızamığa bağı mortaliteyi azaltmaktadır (2,6). 96203 anne ve 6 ay altı 59042 bebeğin alındığı 13 randomize kontrollü çalışmayı içeren bir araştırmada anneye veya bebeğe vitamin A desteği verilmesinin bebeklerdeki mortalite ve morbiditeye etkisi gösterilememiştir (33).

Vitamin C ile ilgili çalışmalara bakıldığında profilaktik veya tedavi edici dozda $\mathrm{C}$ vitamini verilmesinin pnömoni insidansını azalttığı gösterilmiştir. Ancak bu konu ile ilgili yeterli sayıda randomize kontrollü çalışma olmamasına rağmen, maliyeti ve riskleri düşük olması da göz önüne alındığında pnömoni tedavisinde vitamin C desteği uygulanabilir (2).

Vitamin D desteğinin çocuklarda pnömoni insidansı ve ciddiyetine olan etkisi tam olarak bilinmemektedir. 11 plasebo kontrollü çalışmayı içeren 5660 hastanın incelendiği bir meta analizde vitamin D desteği verilmesinin solunum yolu enfeksiyonlarına karşı koruyucu olduğu (OR=0.64 \%95 Güven aralığı=0.49-0.84) gösterilmiştir (34). Vitamin D eksikliğinin çocuklarda tüberküloz enfeksiyonu ve tüberküloz hastalığı ile de ilişkili olduğu bildirilmiştir (2).

Çinko desteği verilmesinin, çeşitli çalışmalarda pnömoniye bağlı daha düşük morbidite ve mortalite riskleriyle ilişkili olduğu gösterilmiştir. Çocuklarda 2 ay-5 yaş arasında çinko desteği verilmesinin pnömoni insidansını \%13 azalttığı bildirilmiştir. Bu nedenle de günlük veya haftalık çinko desteği verilmesinin morbiditeye olan etkisi ile pnömonide gereksiz antibiyotik kullanımını da azaltarak faydalı olabileceği düşünülmektedir $(2,3)$.

\section{- Çocuklarda Kronik Solunum Yolu Hastalıklarında Beslenmenin Önemi}

Malnütrisyon ve tekrarlayan akut solunum yolu enfeksiyonları kronik akciğer hastalıklarının gelişimine neden olmakta ve hastalığa bağlı ciddi sonuçlara yol açmaktadır. Bu nedenle de beslenme kronik akciğer hastalıklarında hastalığın klinik gidişine etkilerinden dolayı önemli yer tutmaktadır (2). Çocukluk çağı astımı ile ilgili yapılan prospektif bir çalışmada, yenidoğan dönemindeki akciğer gelişiminin ve solunum fonksiyonlarının astım riski ile ilişkili olduğu gösterilmiştir (35).

Kistik fibrozis, interstisiyel akciğer hastalıkları, bronşektazi, primer siliyer diskinezi gibi kronik akciğer hastalıklarında çocukluk çağında beslenmenin iyileştirilmesinin daha iyi solunum fonksiyonları ile ilişkili olduğu gösterilmiştir. Bu nedenle de erken dönemde beslenme durumunun kontrol edilmesi ve önlemlerin alınması hastaların ileri yaștaki prognozunu olumlu etkilemektedir (2). Anne sütü ile beslenen çocukların mama ile beslenen çocuklara göre vizing insidansının daha düşük olduğu görülmüştür. Diyetteki vitamin $\mathrm{D}$, poliansature yağ asitleri, antioksidanlar ile astım insidansı arasındaki ilişki bilinmektedir. Ancak bu besin ögelerinin desteklenmesinin astım klinik gidiși ile ilişkisini kanıtlayan yeterli sayıda çalışma bulunmamaktadır. Bunun yanında annenin gebelikte beslenme durumu çocukluk çağı astımı ile ilişkili bulunmuştur, gebelikte vitamin D alınması ve poliansature yağ asitleri alımının astıma bağlı hastalık yükünü azalttığı düşünülmektedir. Gelişmekte olan ülkelerde kronik akciğer hastalıklarına yönelik beslenme önerileri ile ilgili yeterli çalışma bulunmamaktadır (2).

\section{5. Çocuklarda Malnütrisyonu Önlemeye Yönelik Yapılması Gerekenler}

Çocukların büyüme ve gelişmesinin hızlı olduğu yaşamın ilk iki yılında beslenmelerine gereken önem verilmelidir. Bu nedenle de anne sütüne mümkün olan en kısa sürede başlanması ve ilk 6 ay sadece anne sütü ile beslenmeleri bebeklerin büyümesi ve gelişmesi için önemli bir yere sahiptir. Anne sütü ilk iki yıl devam edilmelidir. Altıncı aydan itibaren, bebeklerin besin intiyaçları arttığından anne sütüne ek olarak tamamlayıcı besinlere geçilmesi önerilir. Tamamlayıcı beslenme, çocuklarda artan intiyaçla birlikte gelişebilecek yetersiz beslenmeyi önlemek amacıyla altıncı ayda başlanmalıdır. Aynı zamanda bebeklerin beslenmesi yeterli miktarda mikrobesin ögelerini de içermelidir (36).

Mikrobesin eksiklikleri vitamin ve minerallerin yetersiz alımına bağlı geliştiğinden özellikle gebelikte ve erken çocukluk döneminde yeterli miktarlarda alınması desteklenmelidir. Örneğin boy kısalığı ve bilişsel fonksiyonlarda azalmaya neden olan iyot eksikliği önlenebilir bir nedendir. Benzer şekilde vitamin A eksikliği beş yaş altı çocuklarda görülen önemli bir halk sağlığı problemi olup, vitamin A desteği uygulaması kızamık ve ishal gibi hastalıklarda mortalite riskini azaltmaktadır (36).

Annenin gebelikte yeterli beslenmesi, iyi bakım alması ve sağlıklı bir ortamda yaşaması, bebeğin sağlıklı olması için ön koşullardan biridir. Bu koşulların uygun olması bebekte düşük doğum ağırlığına neden olabilecek durumların önlenmesi ve tedavi edilmesi için gereklidir. Yenidoğan bebeğin doğum ağırlığı, annebebek sağlığı ve beslenme durumlarının önemli göstergelerinden 
biridir. Düşük doğum ağırlıklı bebeklerin yaşamın illk 28 gününde ölüm riski yüksektir. Ek olarak bu bebeklerin yetişkin dönemde obezite, diyabet gibi kronik hastalık risklerinin daha fazla olduğu bilinmektedir.

Çocukların rutin izlemlerinde büyümenin, yeterli kilo alımı ve boy uzamasının olup olmadığının değerlendirilmesi önlenebilir sorunlarda erken müdahaleler açısından önemli bir yere sahiptir (28).

\section{Beslenme Üzerine Dünya Sağlık Örgütü ve Birleșmiş Milletlerin Hedefleri}

Birleșmiş Milletler (BM) genel kurulu 1 Nisan 2016' da, 20162025 ylları arasındaki süreyi beslenme üzerine 10 yllık eylem planı yllı ilan etti. Bu plana göre on yıllık süre tüm malnütrisyon tiplerini ele almak için iyi bir fırsat olarak düşünülmektedir. DSÖ ve Birleșmiş Milletler Gıda ve Tarım Örgütü (FAO) liderliğindeki BM beslenme üzerine 10 yıllık eylem planı, 6 temel alanda politika eylemi çağrısı yapmaktadır (12):

a. Sağlıklı beslenme için sürdürülebilir, dayanıklı gıda sistemleri oluşturmak;

b. Herkese sosyal koruma ve beslenme ile ilgili eğitim vermek;

c. Sağllk sistemlerini beslenme intiyaçlarına uygun hale getirmek ve temel beslenme müdahalelerinin evrensel olmasını sağlamak;

d. Ticaret ve yatıım politikalarının beslenmeyi iyileştirmesini sağlamak;

e. Her yaşta beslenme için güvenli ve destekleyici ortamlar oluşturmak;

f. Beslenme yönetimini ve hesap verilebilirliği her yerde güçlendirmek ve teşvik etmektir

Sonuç olarak; çocukluk çağı solunum yolu hastalıklarında malnütrisyon önemli bir neden olarak karşımıza çıkmaktadır. Çocukların izlemlerinde büyümenin, yeterli kilo alımı ve boy uzamasının olup olmadığının değerlendirilmesi önlenebilir sorunlarda erken müdahaleler açısından önemli bir yere sahiptir. Beslenme ile ilgili erken müdahalelerin solunum yolu hastalıklarını önlemede ve iyileștirmede etkili olduğu kanitlanmakla birlikte bu konuda yeni araştırmalara intiyaç bulunmaktadır.

\section{KAYNAKLAR}

1. Stocks J, Hislop A, Sonnappa S. Early lung development: lifelong effect on respiratory health and disease. Lancet Respir Med 2013;1:728-42.

2. Karim T, Muhit M, Khandaker G. Interventions to prevent respiratory diseases - Nutrition and the developing world. Paediatr Respir Rev 2017;22:31-7.

3. Walson JL, Berkley JA. The impact of malnutrition on childhood infections. Curr Opin Infect Dis. 2018;3:231-6.
4. UNICEF. Global Nutrition Report 2016: from promise to impact: ending malnutrition by 2030. Available from https://www.ifpri.org/ publication/global-nutrition-report-2016-promise-impact-endingmalnutrition-2030.

5. Rodríguez L, Cervantes E, Ortiz R. Malnutrition and gastrointestinal and respiratory infections in children: a public health problem. Int $J$ Environ Res Public Health 2011;8:1174-2.

6. Arigliani M, Spinelli AM, Liguoro I, Cogo P. Nutrition and Lung Growth. Nutrients 2018;10:919.

7. Sonnenschein-van der Voort AM, Gaillard R, de Jongste JC, Hofman A, Jaddoe VW, Duijts L. Foetal and infant growth patterns, airway resistance and school-age asthma. Respirology 2016;21:674-82.

8. Lange P, Celli B, Agustí A, Boje Jensen G, Divo M, Faner R, et al. Lung-Function Trajectories Leading to Chronic Obstructive Pulmonary Disease. N Engl J Med 2015;373:111-22.

9. Dogaru CM, Nyffenegger D, Pescatore AM, Spycher BD, Kuehni CE. Breastfeeding and childhood asthma: systematic review and meta-analysis. Am J Epidemiol 2014;179:1153-67.

10. Waidyatillake NT, Allen KJ, Lodge CJ, Dharmage SC, Abramson MJ, Simpson JA, et al. The impact of breastfeeding on lung development and function: a systematic review. Expert Rev Clin Immunol 2013;9:1253-65.

11. Lelijveld N, Kerac M, Seal A, Chimwezi E, Wells JC, Heyderman $R S$, et al. Long-term effects of severe acute malnutrition on lung function in Malawian children: a cohort study. Eur Respir J 2017;49:1601301.

12. WHO Malnutrition factsheet 2020. https://www.who.int/ news-room/fact-sheets/detail/malnutrition\#: : text $=47 \% 20$ million $\% 20$ children $\% 20$ under $\% 205$, \% 2D \% 20and $\% 20$ middle\%2Dincome\%20countries.

13. Jones KD, Thitiri J, Ngari M, Berkley JA. Childhood malnutrition: toward an understanding of infections, inflammation, and antimicrobials. Food Nutr Bull 2014;35:S64-70.

14. Zar HJ, Ferkol TW. The global burden of respiratory disease-impact on child health. Pediatr Pulmonol 2014;49:430-4.

15. Walker CLF, Rudan I, Liu L, Nair H, Theodoratou E, Bhutta ZA, O'Brien KL, Campbell H, Black RE. Global burden of childhood pneumonia and diarrhoea. Lancet 2013;381:1405-16.

16. Kotloff KL, Nataro JP, Blackwelder WC, Nasrin D, Farag TH, Panchalingam S, et al. Burden and aetiology of diarrhoeal disease in infants and young children in developing countries (the Global Enteric Multicenter Study, GEMS): a prospective, case-control study. Lancet 2013;382:209-22.

17. Ngari MM, Fegan G, Mwangome MK, Ngama MJ, Mturi N, Scott JAG, et al. Mortality after Inpatient Treatment for Severe Pneumonia in Children: a Cohort Study. Paediatr Perinat Epidemiol 2017;31:233-42.

18. Gupta KB, Gupta R, Atreja A, Verma M, Vishvkarma S. Tuberculosis and nutrition. Lung India 2009;26:9-16.

19. Munthali T, Jacobs C, Sitali L, Dambe R, Michelo C. Mortality and morbidity patterns in under-five children with severe acute malnutrition (SAM) in Zambia: a five-year retrospective review of hospital-based records (2009-2013). Arch Public Health 2015;73:23.

20. Agarwal D, Misra SK, Chaudhary SS, Prakash G. Are we Underestimating the Real Burden of Malnutrition? An Experience From Community-Based Study. Indian J Community Med 2015;40:268-72.

21. Chisti MJ, Ahmed T, Pietroni MA, Faruque AS, Ashraf H, Bardhan $\mathrm{PK}$, et al. Pulmonary tuberculosis in severely-malnourished or HIV- 
infected children with pneumonia: a review. J Health Popul Nutr 2013;31:308-13.

22. Bhat RY, Manjunath N. Correlates of acute lower respiratory tract infections in children under 5 years of age in India. Int J Tuberc Lung Dis 2013;17:418-22.

23. Durbin C, Egan R, Gervasi K, Nadeau N, Neal E, Reich S, et al. The effects of obesity on pulmonary function in children. JAAPA 2017;30:30-33.

24. Lang JE. Obesity and asthma in children: current and future therapeutic options. Pediatr Drugs 2014;16:179-88.

25. Gilliland FD, Berhane K, Islam T, Ribeiro JD, Mendes RT. Obesity and the risk of newly diagnosed asthma in school-age children. Am J Epidemiol 2003;158:406-15.

26. Ferreira MS, Marson FAL, Wolf VLW, Ribeiro JD, Mendes RT. Lung function in obese children and adolescents without respiratory disease: a systematic review. BMC Pulm Med 2020;20:281.

27. Winck AD, Heinzmann-Filho JP, Soares RB, da Silva JS, Woszezenki CT, Zanatta LB. Effects of obesity on lung volume and capacity in children and adolescents: a systematic review. Rev Paul Pediatr 2016;34:510-7.

28. Castro-Rodríguez JA, Holberg CJ, Morgan WJ, Wright AL, Martinez FD. Increased incidence of asthma like symptoms in girls who become overweight or obese during the school years. Am $J$ Respir Crit Care Med 2001;163:1344-9.
29. Daar G, Sarı K, Gencer ZK, Ede H, Aydın R, Saydam L. The relation between childhood obesity and adenotonsillar hypertrophy. Eur Arch Otorhinolaryngol 2016;273:505-9.

30. Bailey RL, West KP Jr, Black RE. The epidemiology of global micronutrient deficiencies. Ann Nutr Metab 2015;66 Suppl 2:2233.

31. Nakao RM, Kennedy KI, Savina G. Breastfeeding education and infant health in the rural Philippines. Ecol Food Nutr 1992;27:11526.

32. Osendarp SJ, van Raaij JM, Darmstadt GL, Baqui AH, Hautvast JG, Fuchs GJ. Zinc supplementation during pregnancy and effects on growth and morbidity in low birthweight infants: a randomised placebo controlled trial. Lancet 2001;357:1080-5.

33. Gogia S, Sachdev HS. Vitamin A supplementation for the prevention of morbidity and mortality in infants six months of age or less. Cochrane Database Syst Rev 2011;10:CD007480.

34. Bergman P, Lindh AU, Björkhem-Bergman L, Lindh JD. Vitamin D and Respiratory Tract Infections: A Systematic Review and Meta-Analysis of Randomized Controlled Trials. PLoS One 2013;8:e65835.

35. Bisgaard H, Jensen SM, Bønnelykke K. Interaction between asthma and lung function growth in early life. Am J Respir Crit Care Med 2012;185:1183-9.

36. 2020 Global Nutrititon Report, Children, Food and Nutrition. https://www.unicef.org/media/60806/file/SOWC-2019.pdf 